\title{
The saker falcon (Falco cherrug) population, diet and nest boxes in Slovakia: LIFE-project report 2011-2014
}

\author{
Populácia sokola rároha (Falco cherrug), potrava a hniezdne búdky na Slovensku: \\ správa LIFE projektu za roky 2011 až 2014
}

\author{
Jozef CHAVKO, Roman SLOBODNÍK, Lucia DEUTSCHOVÁ, Ján LIPTÁK, Jozef MIHÓK, Ján OBUCH \\ \& Vladimír NEMČEK
}

\begin{abstract}
From October 2010 until December 2014 the LIFE09 NAT/HU/000384 project was implemented in four Special Protected Areas in Slovakia. The recent project was complementary to a previous LIFE project implemented between 2006 and 2010. Both projects supported regular monitoring of the population of saker falcon and new approaches to conservation of the species. The LIFE09 project helped to increase knowledge about the prey composition and the behaviour of the species. The population was strongly affected in 2013 by extremely bad weather conditions (1.79 fledglings/breeding attempt). Although the total number of saker falcon pairs in Slovakia is thought to be higher, 31 pairs were breeding in 2014. By analysis of the diet (2991 individuals), 47 prey species were identified, from which birds were predominant $(80 \%)$. More than half of the diet consisted of feral pigeons (Columba livia f. domestica) (59\%).
\end{abstract}

Abstrakt: Od októbra 2010 do decembra 2014 bol realizovaný projekt LIFE09 NAT/HU/000384 v štyroch Chránených vtáčích územiach na Slovensku. Projekt nadviazal na predchádzajúci LIFE projekt, realizovaný v rokoch 2006 až 2010 . Oba projekty podporovali pravidelné sledovanie populácie sokola rároha a nové prístupy pre zachovanie druhu. Projekt LIFE09 prispel k zvýšeniu poznatkov o zložení potravy a rovnako aj o správaní sa tohto druhu. Populácia bola silne ovplyvnená v roku 2013 mimoriadne zlými poveternostnými podmienkami počasia (1,79 vyleteného mlád’ata na započaté hniezdenie). Aj ked' sa predpokladá, že celková populácia je vyššia, v roku 2014 bolo zistených na Slovensku spolu 31 párov sokola rároha. Analýzou potravy (2991 jedincov), bolo identifikovaných 47 druhov koristi, z ktorých vtáky boli dominantné (80 \%). Viac ako polovicu potravy tvoril holub domáci (Columba livia f. domestica) (59\%).

Key words: breeding population, saker falcon, artificial nest, diet composition, project report

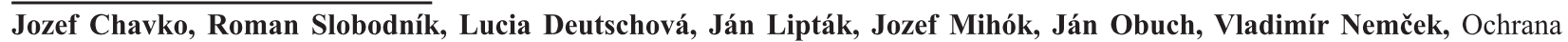
dravcov na Slovensku (Raptor Protection of Slovakia), Kuklovská 5, 84104 Bratislava, Slovakia. E-mail: chavko@dravce.sk, slobodnik@dravce.sk,deutschova@dravce.sk.

Acknowledgements: We would like to thank Michal Ambros, Juraj Andre, Andrej Bača, Martin Čukan, Dalibor Greguš, Martin Gič, Richard Galaš, Ervín Hapl, Peter Hlocký, Tomáš Hulík, Jozef Izakovič, František Karika, Matúš Kováč, Peter Kováčik, Milan Královič, Denisa Löbbová, Jozef Lengyel, Metod Macek, Boris Maderič, Michal Noga, Michal Novák, Karin Očenášová, Ján Orlovský, Leonidas Prešinský, František Szkuby, Ján Sekereš, Daniela Stanislavová, Tibor Šnajdár, Karol Šotnár, Dagmar Tomková, Jozef Tóth, Fridrich Tóth, AGROSPOL Hradová s.r.o., Tisovec, Západoslovenská energetika a.s., Východoslovenská energetika a.s., State Nature Conservancy of the Slovak Republic and Ministry of Environment of the Slovak Republic for their contribution to conservation of saker falcon in Slovakia. Also we would like to thank Marek Gális, Luboš Vadel and Michal Hudec for their help with the statistic evaluation. We would also like to thank Benjamín Jarčuška and an anonymous reviewer for the valuable advice and comments. This article includes results of the project LIFE09 NAT/HU/000384 supported by the European Commission under LIFE Nature program.

\section{Introduction}

The saker falcon (Falco cherrug) is a species of the Palearctic. It is widespread in Asia, mostly in the foreststeppe and steppe areas of Mongolia, Tibet and Russia. In Europe, the species is widespread in Romania, Hungary, Serbia, Austria, Czech Republic and Slovakia. The European population comprises $300-350$ pairs $(1 \%$ of the global population) (Chavko 2002). In the past, the species copied the area of its dominant prey, the European ground squirrel (Chavko 2002), and did so in Slovakia, as well. After 1945, the population in Slovakia decreased (Ferianc 1977) until it became endangered by extinction (5-10 pairs remaining) in the 1980s (Chavko 2002, Chavko \& Deutschová 2012). Recently (mainly 
since 2000), the species has recorded considerable changes from the viewpoint of the breeding and its diet (Chavko \& Deutschová 2012).

The trend of the saker falcon population in western Slovakia and conservation efforts from 1976 until 2010 has been presented by Chavko (2010) and Chavko \& Deutschová (2012). In this article results gathered since 2011 will be presented. Thus, the aim of this article is to evaluate the saker falcon population in Slovakia over the last 4 years and to evaluate its diet in western Slovakia.

\section{Material and methods}

Regular monitoring of the saker falcon population was carried out in western (Fig. 1) and eastern Slovakia. All known and potential breeding sites were checked during the monitoring. The nest boxes installed on high-voltage pylons (see Chavko \& Deutschová 2012 for more details) were checked during the monitoring to identify their occupancy. In monitoring the population, we re- corded four basic parameters: the territory by occupied a pair, whether there was any breeding attempt in the occupied territory, the success rate of breeding and the number of fledglings that flew away. We consider the case of at least one young bird flying from the nest as being a successful nesting. Each breeding attempt was characterized from the viewpoint of a breeding attempt in the following cases: nest box on a pylon, artificial nest on a pylon, artificial nest on a tree or natural nest on a tree. From 2011 to 2013 we monitored the ecological aspects of saker falcon nesting, while considering that the population of the examined species was nesting mostly in nest boxes or in artificial nests on high voltage pylons and in an artificial nest on a tree in from 2011 to 2014. We paid attention mainly to the evaluation of nesting conditions on the pylons and to the factors associated with bringing food and feeding. The diet monitoring was carried out using three methods: by collection and analysis of the dietary residues, by using photo traps and by using a webcam. For evaluation of

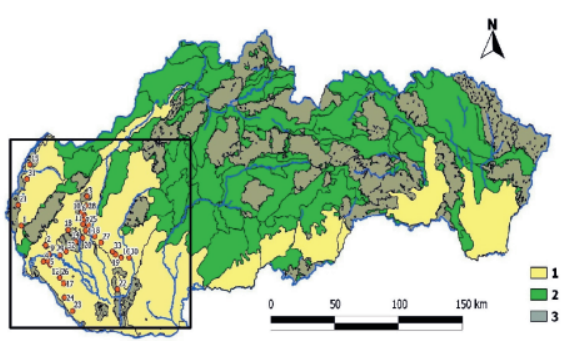

Fig. 1. Nesting territories of the saker falcon in western Slovakia (2011-2014). Altitude 1 (yellow) - 110-250 m a.s.l., 2 (green) - > $250 \mathrm{~m}$ a.s.I., 3 (grey) - Special Protected Area (SPA). Red point - nesting territory; numbers (1-33), number of nesting territory. SPA 1 - Záhorské Pomoravie, 2 - Vel'koblahovské rybníky, 3 Úl'anská mokrad', 4 - Tríbeč, 5 - Špačinskonižnianske polia, 6 - Sĺňava, 7 - Ostrovné lúky, 8 - Malé Karpaty, 9 - Lehnice, 10 - Král'ová, 11 - Dunajské luhy, 12 - Dolné Považie.

Obr. 1. Hniezdne teritóriá sokola rároha na západnom Slovensku (2011-2014). Nadmorská výška 1 (žltá) - 110-250 m n. m., 2 (zelená) - > 250 m n. m., 3 (sivá) - Chránené vtáčie územie. Červený bod - hniezdne teritórium; čísla (1-33) - číslo hniezdneho páru. CHVú 1 - Záhorské Pomoravie, 2 - Vel'koblahovské rybníky, 3 Úlanská mokrad', 4 - Tríbeč, 5 - Špačinskonižnianske polia, 6 - Sĺňava, 7 - Ostrovné lúky, 8 - Malé Karpaty, 9 - Lehnice, 10 - Král'ová, 11 - Dunajské luhy, 12 - Dolné Považie.

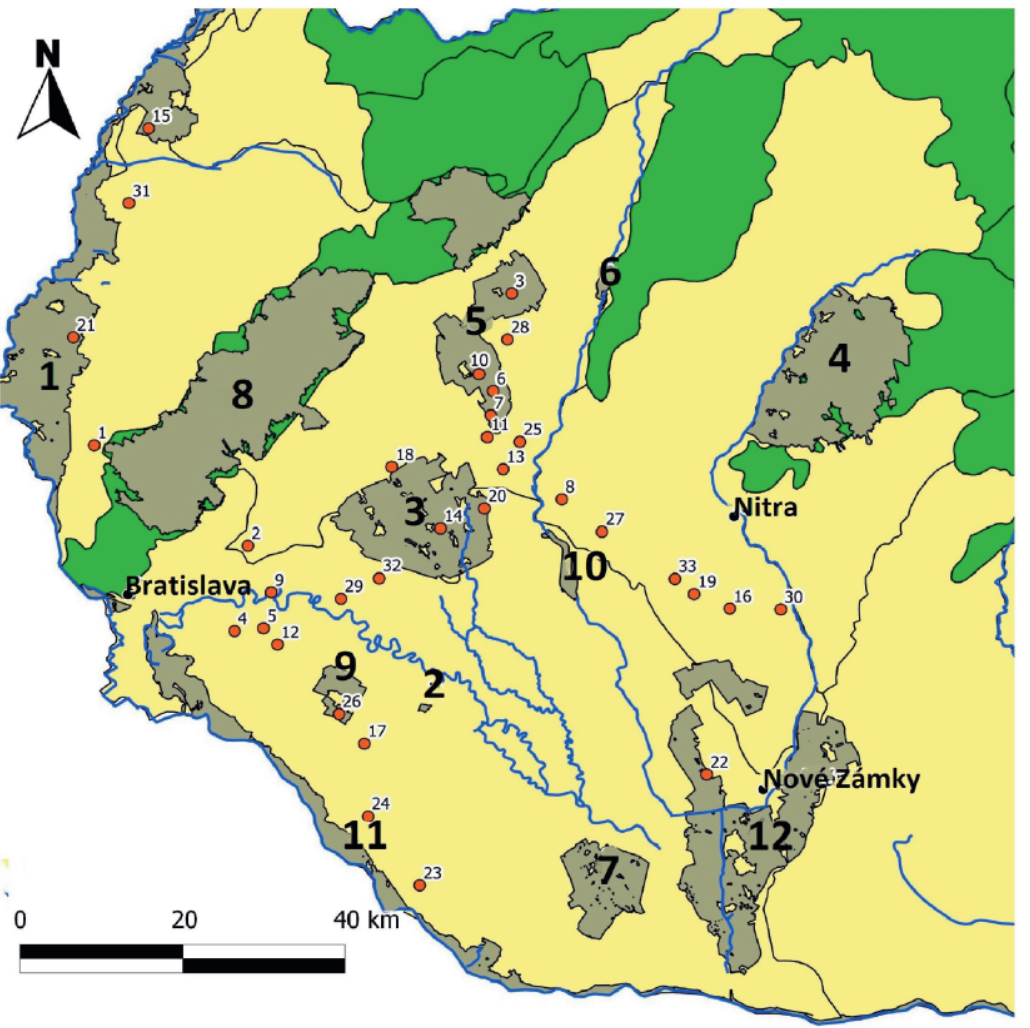


the nesting conditions and prey composition we used 86 thousand photographs taken by photo traps from 2011 until 2013. We used 25 thousand photographs taken by photo traps to evaluate the factors of bringing food and feeding, and from the results of recording 495 hours of daily routine with a video camera in 2013, we succeeded in acquiring data from a single time period, from hatching until fledglings period. In addition, we collected dietary residues from nests of the western Slovakia population after the fledglings period of 33 pairs in the years 2011 until 2013. Data documentation was carried out using ScoutGuard SG $550 \mathrm{~V}$ photo traps and a Geovision 1.3 MPx webcam. The photo traps were set such that three photographs would be taken every minute upon detecting movement. The webcam was set to shoot ceaselessly from dawn till dusk and was turned off at night. However, in both cases some drop-outs were noticed: in some cases the photo traps did not record movement in the nest for some unknown reason, and the webcam did not record during heavy rains. The dominance of the foraging range species in the individual years (seasons) was counted in a standard way according to Losos et al. (1985), i.e. as a percentage of the particular species in the monitored nests in the given year (season). Nomenclature for bird species follows Kovalik et al. (2010) and for mammals species follows Lupták (2003).

\section{Data analysis}

For a comparison of the diet composition from a qualitative and quantitative point of view between different nests and years (from 2011 to 2013), respectively, the indirect gradient principal component analysis (PCA) was used, as the length of the gradient ascertained from the detrended correspondence analysis (DCA) was 2.099 and 0.916 for the analysis of nests and years, respectively. As input data, we used the relative abundance (number) of the ascertained diet species for the individual nests and years, respectively. Considering the distinct difference in the number of available dietary residues in the particular nests (4 individuals min., 196 individuals max., $\mathrm{n}=42$ nests), only nests with more than 20 individuals of prey determined in the nest $(\mathrm{n}=$ 34) were used in analysis of the diet composition between different nests. Thus we used the final matrix comprising 47 lines (prey species) and 34 columns (nests). Full dataset ( $\mathrm{n}=42$ nests) was used for analysis of the diet composition between different years.

In PCA analysis, the square-root transformation of species data was performed. Scaling was set on the interspecies correlations, centering was set by the samples. These analyses were performed with the software CANOCO 4.5 (Microcomputer Power, USA; Ter Braak and Šmilauer, 2002).

The relative diet abundances were used for statistical data processing in STATISTICA 8 (StatSoft, USA). For assessment of statistically significant differences in the relative prey species abundances between 2011 and 2013, we used the Kruskal-Wallis ANOVA test, and the Mann-Whitney $U$ test was used to compare the individual years on the level of significance $\alpha=0.05$.

\section{Results}

P o p u lat i o n c h a n g e s

In the study period (2011-2014) from 36 to 44 occupied territories were recorded in Slovakia (Tab. 1). In 2011, the most pairs-occupied territories (44) and nesting at the same time (43) were recorded, while in 2014, the fewest occupied territories (36) and breeding attempts (31) were recorded. The highest number of successfully breeding pairs was recorded in 2011 (36) and the lowest in 2013 (21). The highest breeding success was 2.9 fledglings/all breeding attempts and 3.7 fledglings/successful breeding attempts in 2012, the lowest was in 2013 (1.79/breeding attempt), the highest in 2014 (3.10/breeding attempt). The lowest total number of fledglings was recorded in 2013 (61), the highest in 2012 (112) (Tab. 1).

The species strongly preferred nesting in nest boxes on high voltage pylons $(93 \%$, Tab. 2). We recorded nesting in artificial nests on high voltage pylons only in a small number of cases (5\%). For the last 4 years, only 2 breeding attempts were recorded in artificial nests on trees. Only one pair bred in a natural nest, on a tree in western Slovakia in 2011 (Tab. 2).

\section{D i e t c o m p o s it i o n}

Through the years 2011-2013 approximately 2991 individuals of prey of the saker falcon were collected from 42 nests in western Slovakia (Tab. 3). The eudominant species of prey was the common pigeon (Columba livia f. domestica) with an overall abundance $58.81 \%$ in all nests. Its frequency varied from 14.81 to $83.17 \%$ in particular nesting localities.

The dominant prey species were the European hamster (Cricetus cricetus), the common starling (Sturnus vulgaris) and the common vole (M. arvalis). Another 
Tab. 1. Saker population trend between 2011 and 2014 in western and eastern Slovakia.

Tab. 1. Populačný trend sokola rároha v rokoch 2011 až 2014 na západnom a východnom Slovensku.

\begin{tabular}{|c|c|c|c|c|c|c|c|c|}
\hline \multirow[b]{2}{*}{$\begin{array}{l}\text { year / } \\
\text { rok }\end{array}$} & \multicolumn{3}{|c|}{ western Slovakia / západné Slovensko } & \multicolumn{3}{|c|}{ eastern Slovakia / východné Slovensko } & \multirow[b]{2}{*}{$\begin{array}{l}\text { successful } \\
\text { breeding } \\
\text { attempts / } \\
\text { úspešné } \\
\text { hniezdne } \\
\text { pokusy }\end{array}$} & \multirow[b]{2}{*}{$\begin{array}{l}\text { number of } \\
\text { fledglings / } \\
\text { počet } \\
\text { vyletených } \\
\text { mlád'at }\end{array}$} \\
\hline & $\begin{array}{l}\text { occupied } \\
\text { territories / } \\
\text { obsadené } \\
\text { teritóriá }\end{array}$ & $\begin{array}{l}\text { all breeding } \\
\text { attempts / } \\
\text { všetky } \\
\text { hniezdne } \\
\text { pokusy }\end{array}$ & $\begin{array}{l}\text { successful } \\
\text { breeding } \\
\text { attempts / } \\
\text { úspešné } \\
\text { hniezdne } \\
\text { pokusy }\end{array}$ & $\begin{array}{l}\text { number of } \\
\text { fledglings / } \\
\text { počet } \\
\text { vyletených } \\
\text { mlád'at }\end{array}$ & $\begin{array}{l}\text { occupied } \\
\text { territories / } \\
\text { obsadené } \\
\text { teritóriá }\end{array}$ & $\begin{array}{l}\text { all breeding } \\
\text { attempts / } \\
\text { všetky } \\
\text { hniezdne } \\
\text { pokusy }\end{array}$ & & \\
\hline 2011 & 31 & 31 & 26 & 84 & 13 & 12 & 10 & 26 \\
\hline 2012 & 30 & 27 & 19 & 70 & 12 & 12 & 11 & 42 \\
\hline 2013 & 27 & 23 & 14 & 40 & 12 & 11 & 7 & 21 \\
\hline 2014 & 28 & 23 & 19 & 70 & 8 & 8 & 7 & 26 \\
\hline
\end{tabular}

Tab. 2. Various types of saker falcon nesting in Slovakia from 2011 to 2014.

Tab. 2. Rôzne typy hniezdenia sokola rároha v rokoch 2011 - 2014 na Slovensku.

\begin{tabular}{|c|c|c|c|c|c|}
\hline type of a nest / typ hniezda & 2011 & 2012 & 2013 & 2014 & 2011-2014 \\
\hline nest box on a pylon / búdka na el. stípe & 40 & 36 & 31 & 29 & 136 \\
\hline artificial nest on a pylon / umelé hniezdo na el. stípe & 2 & 3 & 2 & 1 & 8 \\
\hline artificial nest on a tree / umelé hniezdo na strome & 0 & 0 & 1 & 1 & 2 \\
\hline natural nest on a tree / prirodzené hniezdo na strome & 1 & 0 & 0 & 0 & 1 \\
\hline$\Sigma$ & 43 & 39 & 34 & 31 & 147 \\
\hline
\end{tabular}

three species recorded in dietary residues $(\mathrm{n} \geq 2 \%$ ) were the stock dove (Columba oenas), the common hare (Lepus europaeus) and the common pheasant (Phasianus colchicus). The other species recorded in dietary residues were recedent (2) and subrecedent species (38) of prey. The overall abundance of birds (Aves) was $80.14 \%$. The list of all species of prey is summarized in Tab. 3. While observing dietary changes, we analyzed the relationship between the species recorded in the saker falcon diet and their distribution in the individual nests (2011-2013). The result of indirect PCA ordination is the ordination graph (Fig. 2), the first two axes of which explain $83.8 \%$ of species variability (the first axis explain $79 \%$ and the second $4.9 \%$ ).

The first axis explains the species dominance, and the second one explains the foraging range of the individual pairs in relation to the dominant component of the prey. The cluster of nests, numbering 18 and 8, represents the nests with a low percentage of $C$. livia $\mathrm{f}$. domestica in the diet $(15$, or more precisely $33 \%)$. In contrast, the most abundant species in the diet of these nests were other species, such as $M$. arvalis (nest no. 8) or $C$. cricettus (nest no.18). The other cluster is made up of nests 14/2012, 27 and 33/2012. In these nests, the percentage of feral pigeon is increasing (32-47\%), while the percentage of other species, such as M. arvalis, C. cricettus and also S. vulgaris, is still remains high. Next is the cluster of nests which are close to each other within the foraging range; we are dealing here with the pairs that are rather distant from each other (no.10, 19 or 24), that are close to each other (10 and 25 ), or that use the same nests in two consecutive seasons (no.17 in 2011 and 2012). In these cases, feral pigeon usually comprises half of the diet, while the dominant species are $C$. cricettus and $S$. vulgaris, with L. europaaeus also abundant. Nest number 15 (Fig. 1) is distinctive from the viewpoint of the diet specialization. The most abundant prey species was L. ridibundus $(42 \%)$ in this case. Within the last cluster, consisting of 12 nests, we noted the eudominance of feral pigeon (64-85\%).

Within the monitoring of dietary changes, we analyzed the relations between the species observed in the saker falcon diet and those in the particular breeding seasons (2011, 2012 and 2013). The result of the indirect ordination of PCA is an ordination diagram (Fig. 3), the first two axes of which explain $99 \%$ of species variability (the first axis explains $96.5 \%$ and the second $2.5 \%$ ). The first axis explains the dominance of the species, the second the prey species diversity in the individual breeding seasons. The 13 species displayed on the right side of the graph along the first ordination axis represent the main component of the falcon diet. The common noctule (Nyctalus noctula), the European mole (Talpa europaea) and the common jay (Garrulus glandarius) were absent completely in the saker falcon 
Tab. 3. Diet composition of the saker falcon in western Slovakia between 2011 and 2013.

Tab. 3. Potrava sokola rároha na západnom Slovensku v rokoch 2011 až 2013.

\begin{tabular}{|c|c|c|c|c|c|}
\hline species / druh & 2011-2013 (\%) & $2011-2013(n)$ & $2011(\%)$ & $2012(\%)$ & $2013(\%)$ \\
\hline Columba livia f. domestica & 58.81 & 1759 & 55.13 & 56.21 & 65.36 \\
\hline Cricetus cricetus & 8.93 & 267 & 12.18 & 10.07 & 5.75 \\
\hline Sturnus vulgaris & 8.09 & 242 & 14.10 & 8.55 & 5.98 \\
\hline Microtus arvalis & 6.75 & 202 & 3.85 & 7.53 & 5.52 \\
\hline Columba oenas & 2.81 & 84 & 2.56 & 3.05 & 2.30 \\
\hline Lepus europaeus & 2.31 & 69 & 0.64 & 2.14 & 2.99 \\
\hline Phasianus colchicus & 2.01 & 60 & 1.92 & 1.88 & 2.30 \\
\hline Pica pica & 1.40 & 42 & 0.00 & 1.73 & 0.92 \\
\hline Columba palumbus & 1.34 & 40 & 0.64 & 1.12 & 1.96 \\
\hline Chroicocephalus ridibundus & 0.97 & 29 & 0.64 & 1.02 & 0.92 \\
\hline Perdix perdix & 0.77 & 23 & 0.64 & 0.92 & 0.46 \\
\hline Streptopelia decaocto & 0.70 & 21 & 1.92 & 0.61 & 0.69 \\
\hline Coturnix coturnix & 0.57 & 17 & 0.64 & 0.46 & 0.81 \\
\hline Talpa europaea & 0.53 & 16 & 0.00 & 0.71 & 0.23 \\
\hline Nyctalus noctula & 0.47 & 14 & 0.00 & 0.61 & 0.23 \\
\hline Alauda arvensis & 0.40 & 12 & 0.64 & 0.25 & 0.69 \\
\hline Garrulus glandarius & 0.33 & 10 & 0.00 & 0.05 & 1.04 \\
\hline Vanellus vanellus & 0.33 & 10 & 1.28 & 0.20 & 0.46 \\
\hline Spermophilus citellus & 0.33 & 10 & 0.64 & 0.41 & 0.12 \\
\hline Turdus philomelos & 0.23 & 7 & 0.64 & 0.20 & 0.23 \\
\hline Mus musculus & 0.23 & 7 & 0.00 & 0.36 & 0.00 \\
\hline Streptopelia turtur & 0.13 & 4 & 0.00 & 0.20 & 0.00 \\
\hline Passer domesticus & 0.13 & 4 & 0.00 & 0.20 & 0.00 \\
\hline Passer montanus & 0.13 & 4 & 0.00 & 0.15 & 0.12 \\
\hline Asio otus & 0.13 & 4 & 0.00 & 0.15 & 0.12 \\
\hline Passeriformes & 0.13 & 4 & 0.64 & 0.10 & 0.12 \\
\hline Turdus merula & 0.10 & 3 & 0.00 & 0.10 & 0.12 \\
\hline Psittacidae & 0.10 & 3 & 0.00 & 0.15 & 0.00 \\
\hline Turdus pilaris & 0.07 & 2 & 0.00 & 0.05 & 0.12 \\
\hline Melopsittacus undulatus & 0.07 & 2 & 0.00 & 0.10 & 0.00 \\
\hline Aves & 0.07 & 2 & 0.64 & 0.05 & 0.00 \\
\hline Arvicola amphibius & 0.07 & 2 & 0.00 & 0.10 & 0.00 \\
\hline Lacerta agilis & 0.07 & 2 & 0.00 & 0.10 & 0.00 \\
\hline Apus apus & 0.03 & 1 & 0.00 & 0.05 & 0.00 \\
\hline Corvus monedula & 0.03 & 1 & 0.00 & 0.00 & 0.12 \\
\hline Corvus frugilegus & 0.03 & 1 & 0.64 & 0.00 & 0.00 \\
\hline Lullula arborea & 0.03 & 1 & 0.00 & 0.05 & 0.00 \\
\hline Parus major & 0.03 & 1 & 0.00 & 0.00 & 0.12 \\
\hline Fringilla coelebs & 0.03 & 1 & 0.00 & 0.00 & 0.12 \\
\hline Lanius collurio & 0.03 & 1 & 0.00 & 0.05 & 0.00 \\
\hline Crex crex & 0.03 & 1 & 0.00 & 0.05 & 0.00 \\
\hline Philomachus pugnax & 0.03 & 1 & 0.00 & 0.05 & 0.00 \\
\hline Apodemus sylvaticus & 0.03 & 1 & 0.00 & 0.05 & 0.00 \\
\hline Apodemus microps & 0.03 & 1 & 0.00 & 0.05 & 0.00 \\
\hline Sorex araneus & 0.03 & 1 & 0.00 & 0.05 & 0.00 \\
\hline Rana cf.esculenta & 0.03 & 1 & 0.00 & 0.05 & 0.00 \\
\hline Scorpionida sp. & 0.03 & 1 & 0.00 & 0.00 & 0.12 \\
\hline$\sum$ & 100 & 2991 & 100 & 100 & 100 \\
\hline
\end{tabular}

diet in 2011, but they were found (even though subrecedently or recedently) in 2012 and 2013 . We can generally characterize the species cluster in the left part of the graph along the first ordination axis as a supple- mentary saker falcon diet (24 species), represented in small numbers (or the species did not even occur) in all the seasons. The other cluster is a grouping of species, such as the song trush (Turdus philomelos), the rook 

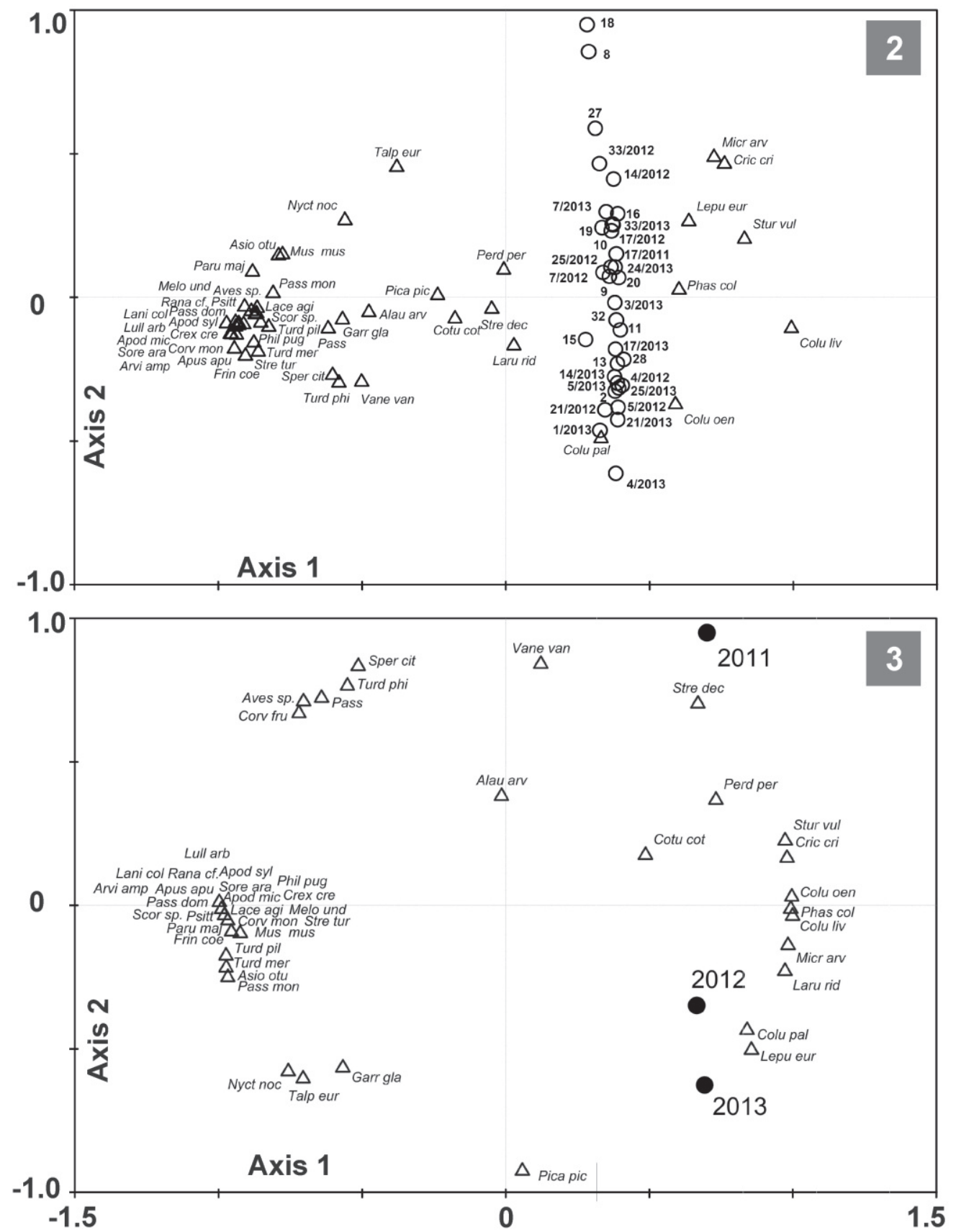

Figs 2-3. PCA graph representing the prey species location of the saker falcon in ordination space (2) with regard to the individual nests (2011-2013), where the first ordination axis explains $79 \%$ and the second axis $4.9 \%$ of the species data variability; and (3) with regard to the breeding seasons $2011-2013$, where the first ordination axis explains $96.5 \%$ and the second axis $2.5 \%$ of the species data variability. Empty circle - nest, full circle - year, triangle - prey species. Species name abbreviation consists of first letters of the genus and the species name (see Tab. 3).

Obr. 2-3. Graf analýzy hlavných komponentov (PCA) znázorňujúci polohu druhov potravy sokola rároha v ordinačnom priestore (2) vzhl'adom k jednotlivým hniezdam (2011 - 2013), kde prvá ordinačná os vysvetluje $79 \%$ a druhá os 4,9\% variability druhových dát; (3) vzhl'adom k hniezdnym sezónam 2011 - 2013, kde prvá ordinačná os vysvetluje $96,5 \%$ a druhá os 2,5 \% variability druhových dát. Prázdny krúžok - hniezdo, plný krúžok - rok, trojuholník - druh potravy. Skratka názvu druhu pozostáva z prvých písmen rodového a druhového mena (vid' Tab. 3). 
Tab. 4. A comparison of diet composition by the method of analysis from the video camera (the second and third column) and analysis of dietary residues (the fourth and fifth column) from nesting pair number 1 in 2013.

Tab. 4. Porovnanie zloženia potravy metódou analýzy z videokamery (druhý a tretí stípec) a analýzy potravných zvyškov (štvrtý a piaty stípec) hniezdeho páru č. 1 v roku 2013.

\begin{tabular}{lrrrr}
\hline species / druh & $\mathbf{n}$ & \multicolumn{1}{c}{$\%$} & $\mathbf{n}$ & \multicolumn{1}{c}{$\%$} \\
\hline Columba livia f. domestica & 61 & 45.19 & 15 & 51.72 \\
Lepus europaeus & 16 & 11.85 & 3 & 10.34 \\
Sturnus vulgaris & 15 & 11.11 & 2 & 6.90 \\
Passeriformes & 11 & 8.15 & 0 & 0.00 \\
Aves & 6 & 4.44 & 0 & 0.00 \\
Microtus arvalis & 6 & 4.44 & 0 & 0.00 \\
unknown / neznáme & 5 & 3.70 & 0 & 0.00 \\
Phasianus colchicus & 5 & 3.70 & 3 & 10.34 \\
Alauda arvensis & 3 & 2.22 & 0 & 0.00 \\
Turdus merula & 2 & 1.48 & 0 & 0.00 \\
Columba oenas & 1 & 0.74 & 1 & 3.45 \\
Corvus corone & 1 & 0.74 & 0 & 0.00 \\
Anas sp. & 1 & 0.74 & 0 & 0.00 \\
Saxicola rubetra & 1 & 0.74 & 0 & 0.00 \\
Talpa europaea & 1 & 0.74 & 0 & 0.00 \\
Vanellus vanellus & 0 & 0.00 & 1 & 3.45 \\
Chroicocephalus ridibundus & 0 & 0.00 & 3 & 10.34 \\
Turdus philomelos & 0 & 0.00 & 1 & 3.45 \\
\hline$\sum$ & 135 & 100 & 29 & 100 \\
\hline
\end{tabular}

(Corvus frugilegus) and unidentified species of songbirds or birds, supplemented by $S$. citellus. These species occurred in the diet of the saker falcon only in 2011 , or in the other years they were originally not determined individuals to the species level (in the case of Passeriformes and Aves sp.). The European ground squirrel was slightly more abundant in the diet in 2011 in comparison with the other monitored years.

A similar statement applies also to northern lapwing (Vanellus vanellus). The collared dove (Streptopelia decaocto) was represented recedently in 2011, while in the other years it occurred only subrecedently. By contrast, the dominant species in all three seasons were: $C$. cricetus, S. vulgaris and mainly C. livia f. domestica. While in case of first two species the share in the diet in the particular years decreases, in the feral pigeon the share in the diet increases (from 55\% in 2011 to $65 \%$ in 2013). The common hare and the wood pigeon, represented subrecedently in 2011 and recedently in 2012 and 2013, also showed an increased share in the last two years.

No statistically significant difference in the abundance of prey species in the nests between the years 2011 until 2013 were found $\left(\chi^{2}=2.066 ; p=0.356\right)$.
When comparing the individual years, we found a statistically significant difference between the years 2011 and 2012, but no statistically significant difference between the years 2011 and 2013 or 2012 and 2013 was found out $(Z=-1.131 ; p=0.258)(Z=0.949 ; p=$ $0.343)$.

By the diet analysis from the webcam, 135 prey individuals were recorded, of which 113 individuals were determined (84\%). Twelve prey species were identified, while $C$. livia $\mathrm{f}$. domestica, L. europaeus and $S$. vulgaris (Tab. 4) were eudominant. Within the foraging range, birds represented $83 \%$ (112 individuals), the rest consisted of mammals. As for the feeding, the activity of the female predominated over the male (74 vs. 9 cases), while in two cases collective feeding occurred.

\section{Discussion}

In the course of the years 2011-2014, a $28 \%$ decrease in the number of breeding pairs occurred (43 breeding attempts in 2011 vs. 31 in 2014). The population of the species in the eastern Slovakia appears to be more vulnerable; in the course of 4 years, a 33\% decrease occurred (12 pairs in 2011 vs. 8 pairs in 2014). From a long-term point of view we can state the stabilization of the population, especially after the increase of nest boxes on offer after 2000 (Chavko 2010). The population of the saker falcon in Slovakia was strongly affected by extremely bad weather in 2013, resulting in a low number of breeding pairs and juveniles. The Slovak population is very fragile and make up for repeated bad breeding seasons with difficulties. Implementation of conservation measures is thus crucial for the saker falcon in Slovakia. The species in Slovakia has reoriented itself, and the population now prefers nest boxes and nests on high voltage pylons in lowlands for breeding, though it originally nested at up to 800 meters above the sea (Chavko 2002). This particular phenomenon is related to the change in the structure of the landscape, which subsequently changes the original foraging conditions of the species (Ambros 2008). The abundance of individual species and the structure of the whole cenoses depend to great extent on the method of landscape management by humans (McDonell \& Pickett 1990, Blair 1996, Rodewald \& Yahner 2001 or Crooks et al. 2004). Primarily in agricultural land the cause of the lower biodiversity is the decrease in the heterogeneity of biotopes (the presence of the forest patches in the area, hydrological conditions or structural diversity) caused mainly by the intensification of agricultural pro- 
duction and by the changes in management practices (Benton et al. 2003, Pykal et al. 1997). In case of the saker falcon, the changes in the landscape brought about a decrease of its main prey in the past - the European ground squirrel. Due to the perishing of the European ground squirrel areas, a change in distribution of the saker falcon came about - it moved to lowlands and changed its prey specialization, with a focus on pigeons, starlings or European hamsters. In terms of time this process was rather quick, with the whole population undergoing this change in the course of 15 years (1994the first case of nesting in lowlands, 2009 - nesting in mountains was not recorded at all; Chavko \& Deutschová 2012). The saker falcon also breeds in nest boxes on high voltage pylons in Hungary, where the breeding population comprises 200 pairs (Bagyura et al. 2004, 2009), and in Czech Republic where the population has increased its numbers and stabilized at 15-20 pairs (Beran et al. 2012), while the estimate of its maximum size is 15-30 pairs (Mrlík et al. 1995). At the same time the species has spread to the north or northwest in Czech Republic, nesting mostly on high voltage pylons but also rarely in other conditions, such as the hollow of a tree (Horal et al. 2006, Horal 2008).

Thus, high voltage pylons represent an important nesting site of the species not only in Slovakia (Chavko 2010) but also in Czech Republic (Beran et al. 2012), Serbia (Puzović 2008) and Austria (Zink et al., unpublished data). In these places the species achieves a higher success rate in comparison with nesting on trees (pylons vs. trees: $83 \%$ vs. $63 \%$ ), which manifests itself in a higher number of juveniles ( 3 vs. 1.9 juveniles per one nesting, Chavko 2010). Other studies of the biology of other raptor species have also come to similar conclusions, i.e. in the common kestrel ( $F$. tinnunculus) in Germany (Kostrzewa \& Kostrzewa 1993, Hansenclover et al. 1989). Thus the pylons on which the nest boxes are installed represent a new nesting offer for some species (Ellis et al. 1997, Chavko 2010, Zink unpublished data). This new type of breeding habitat also represents a place for researching the ecology of the species in the newly created conditions, e.g. through the installing of photo traps and video cameras. No less important is the advantage of using modern technology for observation of nesting (biology, ecology and ethology of the species and also the nest protection). In the case of nests compared by us from the viewpoint of the diet analysis from the video camera and from the dietary residues, only 16 species were determined (Tab. 4), while 15 species were recorded (13 determined) by video camera and the analysis of dietary residues confirmed only 8 species. In addition, the analysis of dietary residues helped to determine three species that had not been identified by video camera, probably because of several drop-outs in the filming. A significant difference can be seen in the overall amount of prey, when 135 prey individuals were identified by video camera whilst only 29 individuals were identified from prey remains. The stated difference is interpreted through the possibility of removing the undigested residues of the adult individuals or as the result of weather conditions (a part of the diet could be removed during windy weather). It also could be the case of digesting the whole prey, including the bones, by the juveniles, which is typical for raptors in comparison with owls (Hudec 1977).

When comparing our results with the analysis of

Tab. 5. The course of the activities of mating calls and laying eggs of pair number 18 nesting on the artificial nest on a high voltage pylon from March 3 until April 24, 2013.

Tab. 5. Priebeh aktivít toku a znášania vajec páru č. 18 hniezdiaceho na umelom hniezde na stožiari v období od 3 .marca do 24. apríla 2013.

installing of a photo trap / inštalovanie fotopasce

the first flying in of saker falcon / prvý prílet rároha

the mating call / tok

the mating call recorded in the nest / tok zaznamenaný na hniezde

laying of the first egg / znesenie prvého vajca

laying of the second egg / znesenie druhého vajca

laying of the third egg / znesenie tretieho vajca

laying of the fourth egg / znesenie štvrtého vajca

the time between laying of the first and the last egg /

čas medzi znesením prvého a posledného vajca

the average interval of laying the eggs / priemerný interval znášania vajec

the first sitting down on the eggs / prvé zasadnutie na znášku

termination of the photo trap activity / vyvrcholenie aktivity zaznamenanej fotopascou

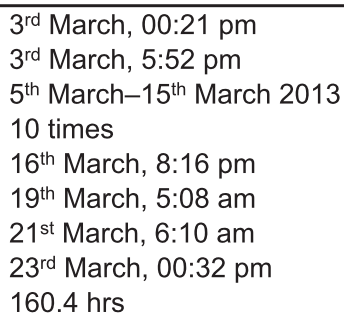

$3^{\text {rd }}$ March, 00:21 pm

$3^{\text {rd }}$ March, 5:52 pm

$5^{\text {th }}$ March-15th March 2013

10 times

$16^{\text {th }}$ March, 8:16 pm

$19^{\text {th }}$ March, 5:08 am

21 ${ }^{\text {st }}$ March, 6:10 am

23rd March, 00:32 pm

$160.4 \mathrm{hrs}$

$53.4 \mathrm{hrs}$

23th March 2013, 6:19 pm

$24^{\text {th }}$ April 2013 
data from 1976-2010 (Chavko \& Deutschová 2012) we can observe the following: Columba livia f. domestica remains eudominant, and $S$. vulgaris and $C$. cricetus are dominant. A significantly lower representation occurred in $P$. perdix and S. citellus, by which a considerable decrease was recorded in Slovakia during the last decades (Trnka 2002, Ambros 2008). Probably and partially as a compensation for the two species mentioned above, we state a higher share of the common vole in the diet, with its abundance significantly increasing during the last three years in comparison with the previous period $(1.7 \%$ vs. $6.75 \%)$. The main breeding season prey in Central Europe (e.g. Hungary) is birds, especially feral pigeons (C. livia f. domestica) (Bagyura et al. 2006), but also voles. Mammals (especially sousliks) are still the predominant prey in Eastern Europe (Moldova and Ukraine), Turkey (Dixon et al. 2009) and Kazakhstan (Nedyalkov et al. 2014). This basic difference in the diet of the saker falcon in Central Europe when the replacement of the decreasing population of the European ground squirrel by the pigeon came about is also documented by other works (Frey \& Senn 1980, Bagyura et al. 1994, Horák 1998, Obuch \& Chavko 1997).

By the analysis using the photo trap some factors about the primary nesting structure were discovered (Tab. 5). In the photographs the interspecies interaction of the saker falcon with common kestrel was discovered. The common kestrel reacted to the female saker falcon leaving the nest and showed interest in the nest several times. This fact confirms that nesting opportunities are often a limiting factor of the population of many species, especially in the agricultural land (Bennett et al. 2004, Hinsley \& Bellamy 2000, Mason $\&$ Macdonald 2006). The use of modern technology, such as video cameras and photo traps, has enabled several other ecological and ethological aspects of the saker falcon nesting described below to be discovered or clarified.

On the importance of nest boxes and a landing platform Nowadays, the nest boxes on pylons are the most important reproduction site for the population of the saker falcon in Slovakia. We can assume that their quality, technical arrangement and location have an impact on breeding success. In Slovakia, nest boxes made from aluminium metal plates of 2-2.5 mm of thickness and $60 \times 60 \mathrm{~cm}$ in size are used. The nest box is open only in the front where a platform is placed serving as a landing area before entering the nest box (Fig. 4). The bottom measures $60 \times 60 \mathrm{~cm}$. There are 16-20 openings of 7-8 $\mathrm{mm}$ across drilled to the bottom. The base of the platform is also made from aluminium, and the top of the platform is made from wood with artificial grass on top. Underneath the roof there used to be a mirror serving as a comfortable control from the ground, enabling visual control of the content of the nest box with binoculars.

The data from photo traps and the video camera have confirmed the importance of the landing platform for the birds occupying the nest box. Several kinds of use of the platform by saker are shown in Fig. 5 .

Based on the analysis of pictures from photo traps and the video camera, as well as based on observations of experts in Slovakia during the last 10 years, the use of this type of nest box with a platform is important especially for:

- feeding of the nestlings - the adult bird lands on the platform with the prey and feed the chicks which are inside the nest box,

- fledglings and juveniles practicing with their wings before leaving the nest,

- prevention of contact with the iron construction of the pylon and thus, preventing damage to the claws,

- prevention of static electricity thanks to the wooden construction compared with the iron construction of the pylon,

- day and night roosting of birds also during the nonbreeding season,

- improving the protection of fledglings by a male or female sitting on the platform.

The platform can be considered as an imitation edge

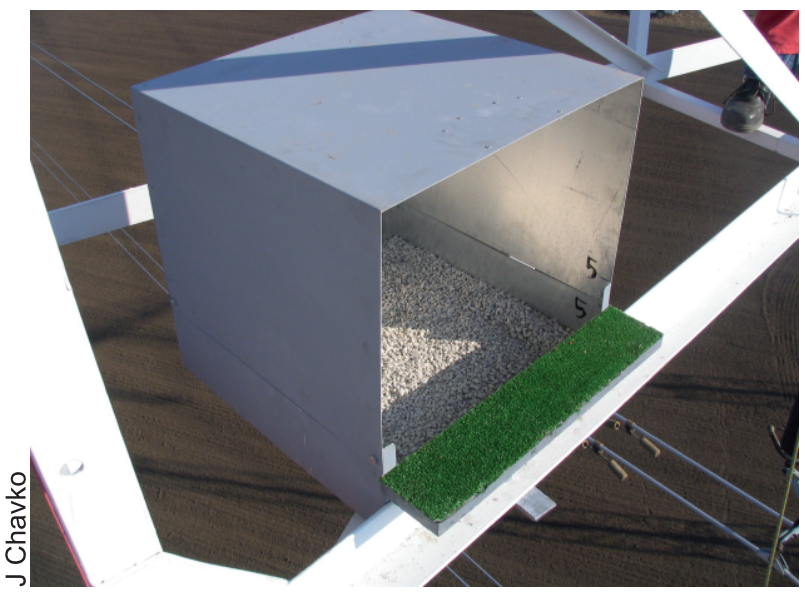

Fig. 4. Prototype of nest box intended for the saker falcon. Obr. 4. Prototyp hniezdnej búdky určenej pre sokola rároha. 


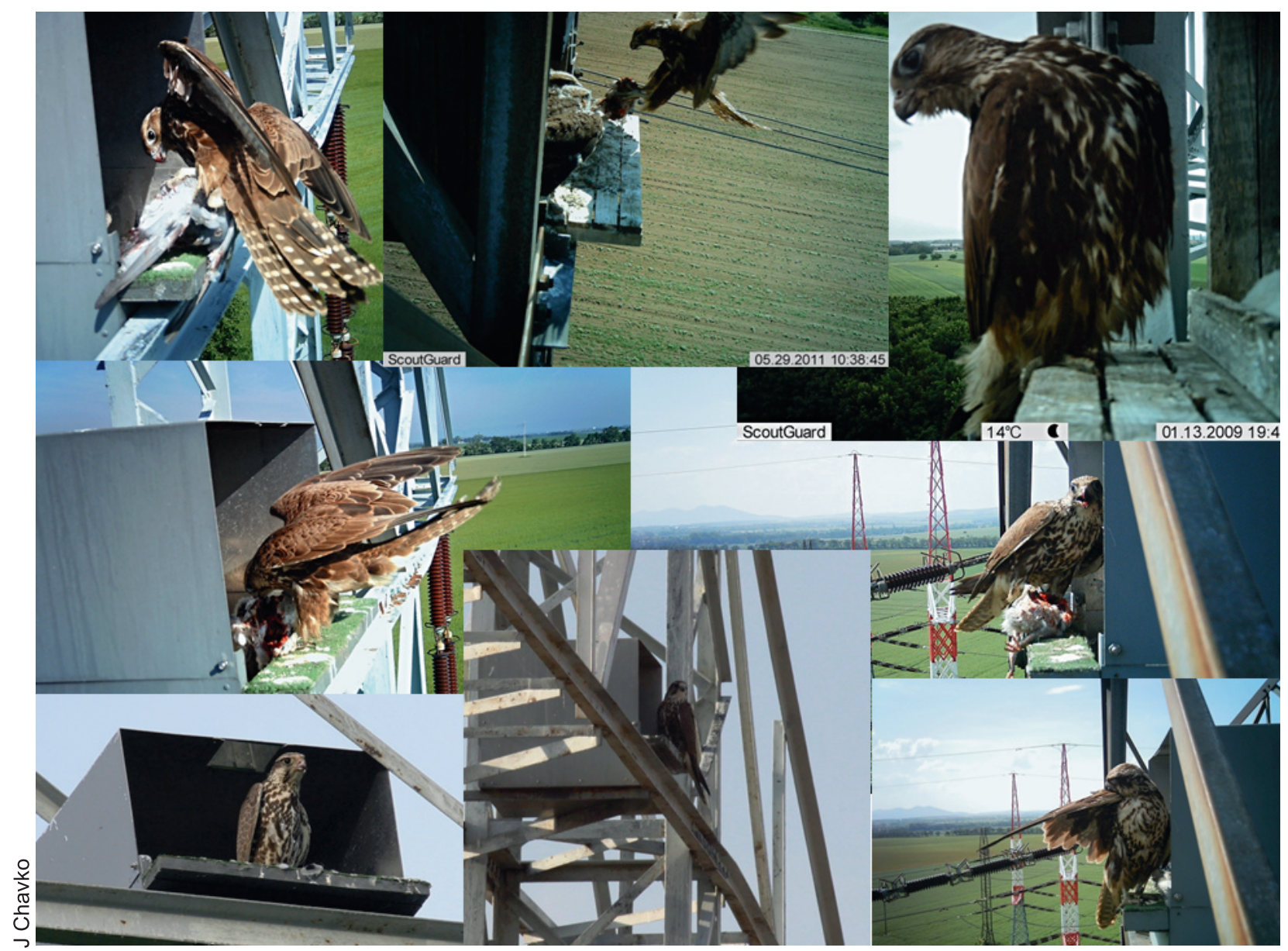

Fig. 5. Use of the landing platform by adult and juvenile saker falcons during the breeding period.

Obr. 5. Využívanie príletovej plošiny dospelými aj mladými sokolmi rárohmi počas hniezdenia.

of a natural nests situated either on a rock or a tree. Nest boxes with a platform are not only used in Slovakia, but also in Czech Republic and Austria (Zink et al., unpublished data). Therefore, we would recommend considering the use of a platform in the future in those countries where it is not currently used, such as Hungary, Bulgaria and Romania.

Interesting observation s

from photo traps

Through analysis of photographs from artificial nestbox number 18 (Fig. 1), located on a high voltage pylon since 2009, we found that both individuals of the pair flew into the nest repeatedly during the whole day from March 4, whilst the female spent the night regularly in the nest. The temperature fluctuated above zero until the time of laying the fourth (and last) egg; the temperature dropped to $-7^{\circ} \mathrm{C}$ on March 23, when the female sat on the eggs and a part of the nest was covered in snow until 2 April (Fig. 6). Three chicks hatched from the 4 eggs and successfully fledged and flew away. During the incubation period, a female of the common kestrel flew and sat on the edge of the nest approximately $30-40 \mathrm{~cm}$ from the incubating female saker falcon 9 times. An employee of the electric company disturbed the female saker falcon and a couple of common kestrels used the absence of the female right after the employee left and uttered a mating call near the eggs of the saker falcon. The female saker falcon flew back to the nest 37 minutes after the electric company employee left.

Mirror in the nest box a s a d i s t u r bing factor

In all nest boxes installed on high-voltage pylons since 


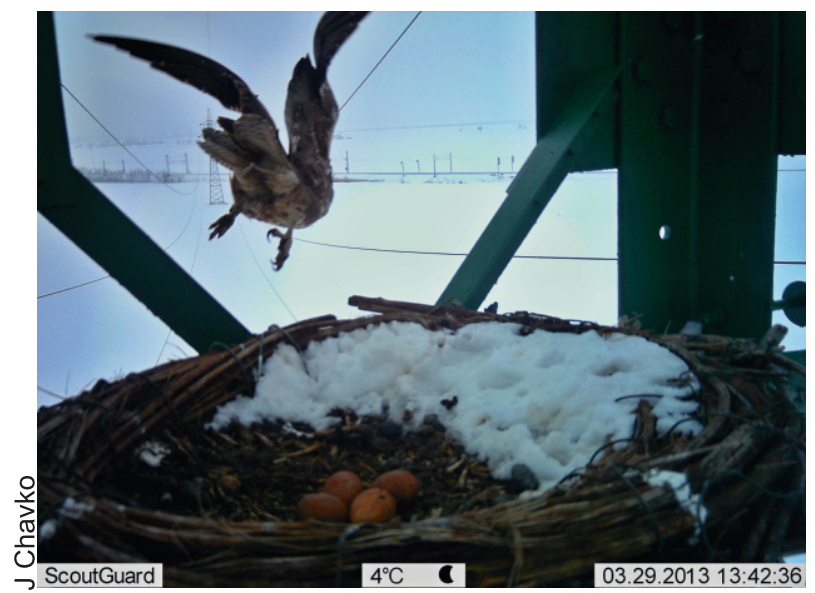

Fig. 6. Picture of photo traps of pair number 18.

Obr. 6. Záznam z fotopasce z hniezda číslo 18.

2004 a mirror was placed inside on the upper side of the box in order to allow us to verify occupancy from the ground. Pictures from photo traps and records from a video camera demonstrate that the mirror can very intensively disturb the breeding birds (Fig. 7). In an evaluation of the function of a mirror serving as a visual control from the ground, we found out that it may cause stress to the pair not only during nesting but also in the non-breeding season (Chavko 2013). The adult individuals perceive their reflection as an intruder and they act territorially. They often gaze with a fixed look at their own reflection and strike against the mirror. In the case of pair number 14, the photo trap recorded 62 cases of stressful activities linked to the mirror. Similar behaviour was observed by the common kestrel. Due to this, we adopted measures and removed the mirrors from the nest boxes. The above mentioned negative impact of the mirror has not yet been mentioned in the literature. The other technical parameters - the size and layout arrangement of the nest boxes - proved to be suitable. An important factor is the orientation of the nest box opening considering the prevailing winds.

Conservation measures i mplemented under LIFE pro$\mathrm{j}$ e c t s

Since 2003 Raptor Protection of Slovakia (RPS) has implemented six projects under the LIFE Nature instrument. These projects have improved the conservation of different bird species and contributed strongly to the

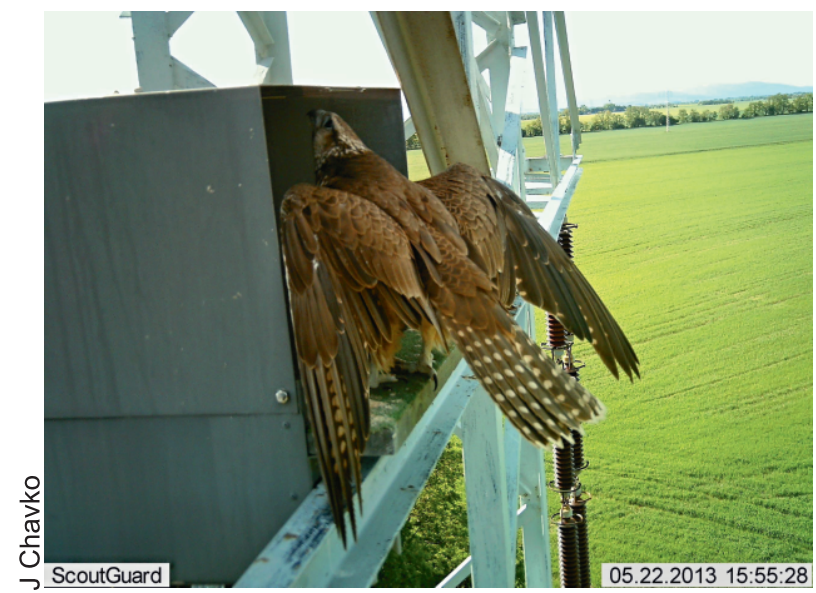

Fig. 7. Mirror in the nest box as a stressful factor in the breeding period of the saker falcon.

Obr. 7. Zrkadlo $v$ búdke ako stresový faktor $v$ priebehu hniezdenia sokola rároha.

development of the material and personnel resources of the organization. Between 2006 and 2014 two LIFE projects focused on the conservation of the saker falcon were implemented in the territory of Slovakia. The second project, LIFE09 NAT/HU/000384 Conservation of Falco cherrug in Northeast Bulgaria, Hungary, Romania and Slovakia, contributed considerably to the conservation of the species in Slovakia.

Several activities were carried out over four years of the project duration, between 2010 and 2014. Regular monitoring of the saker falcon population was carried out in western and eastern Slovakia from LIFE project resources in the project areas and from other resources outside the project areas (Fig. 8). In Slovakia four juvenile females were tagged with a satellite transmitter in areas bordering with the wind power plants in Austria. This activity was focused on the influence of wind power plants on the saker falcon individuals and population. The results are described in detail by Nemček et al. (2014). Five photo traps were used in each year of the project to identify the prey composition by new methods and to protect the nests from robberies and disturbance. A video camera was used on two different nests in 2011 and 2013, in particular to collect data about prey composition. Data on prey composition from the photo traps and the video camera have been analysed.

Activities focused on conservation of the European ground squirrel as an important historical saker falcon prey were implemented, such as to participation in the 


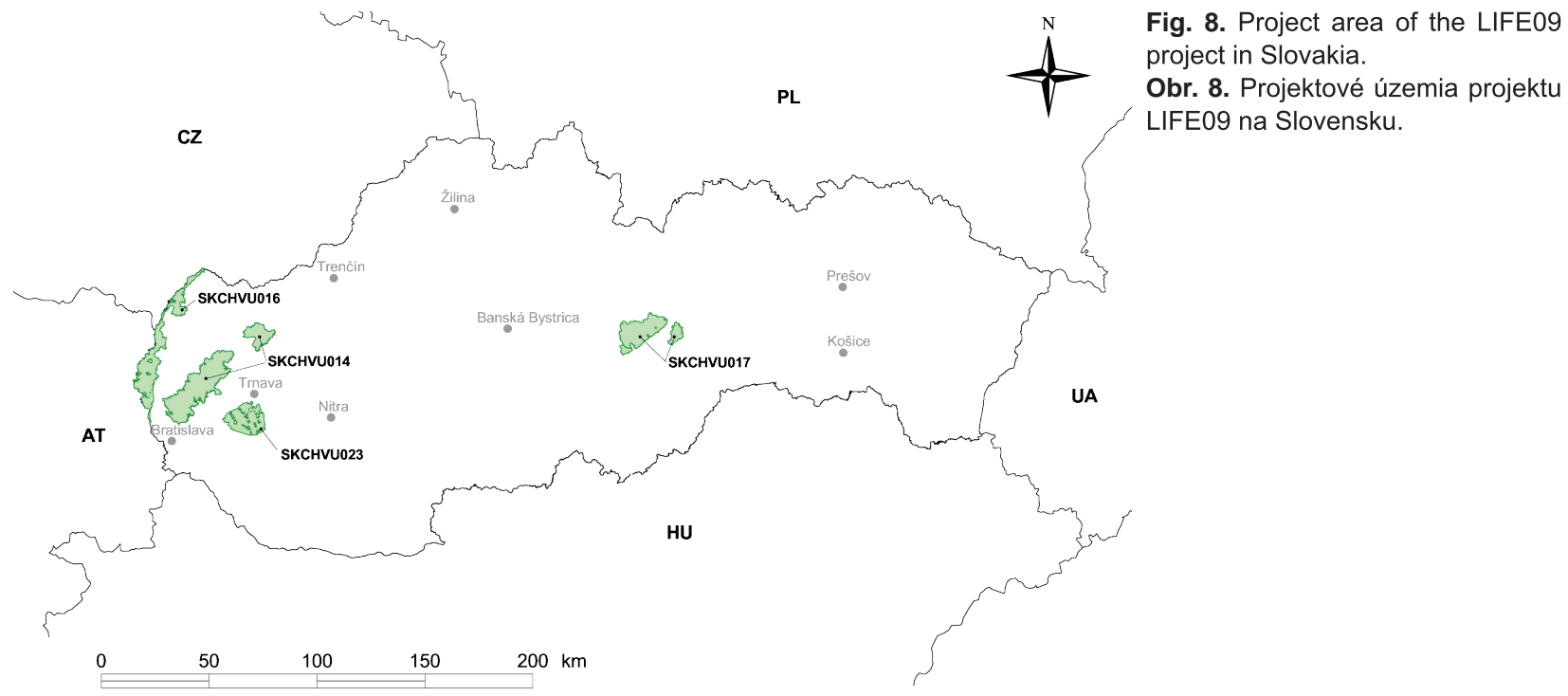

preparation of an agri-environmental scheme (AES) for $S$. citellus and its incorporation into the Rural Development Programme (RDP) for the new period 2014-2020. These efforts were successful, and the AES was adopted by the government as an important tool for support of farmers to apply proper conservation measures. Repatriation of $S$. citellus was being carried out at two sites of 20 hectares each in two SPAs (SKCHVU016 Záhorské Pomoravie and SKCHVU017 Muránska planina - Stolica) (Löbbová \& Hapl 2014). These sites were selected either in the vicinity of a known saker breeding site (SKCHVU016) or in a historical breeding site (SKCHVU017). The farmers on both sites were given subsidies in the amount of 2000 euro each in 2011, 2012 and 2013 as a form of support with implementation of the AES before it was part of the RDP. No nest boxes were installed in the country under the recent project. Two aviaries were built for disabled individuals, in Bratislava and in Ratnovce.

S a k e r f a l c o n s a n d pow e r

\section{$1 \mathrm{i} \mathrm{ne} \mathrm{s}$}

Recent results from satellite telemetry confirm that electrocution represents a serious risk for the saker falcon, especially for juveniles (Nemček et al. 2014), and is one of the main causes of mortality. One of the most important activities of the LIFE09 project was the insulation of dangerous electric poles to protect birds from electrocution in western Slovakia. The responsible electric company Západoslovenská energetika (ZSE) a.s. was included in the project as an associated beneficiary and was responsible for purchase of insulators as well as for their installation. A type of insulator selected by testing under the previous LIFE project was used. A total of 1138 poles were insulated on dangerous $22 \mathrm{kV}$ power lines in the areas identified as the most important for the saker falcon. The efficiency of the insulation was verified by monitoring of the insulated power lines.

\section{References}

Ambros M 2008: Stav poznania rozšírenia sysl'a pasienkového (Spermophilus citellus) na Slovensku v rokoch 1996 až 2008 [Current knowledge on the distribution of the European ground squirrel (Spermophillus cittelus) in Slovakia in 1996-2008]. Lynx (Praha) 39: 219-233.

Antal M 2010: Policy measures to address bird interactions with power lines - a comparative case study of four countries. Ostrich 81: 217-223. DOI: 10.2989/00306525.2010.517921

Bagyura G, Haraszthy L \& Szitta T 1994: Feeding biology of saker falcon in Hungary, 397-401. In Meyburg B-U, Chancellor RD (eds): Raptor conservation today. Pica Press, London, 799.

Bagyura J, Szitta T, Haraszthy L, Demeter I, Sándor I, Dudás M, Kállay Gy \& Viszló L 2004: Population trend of the saker falcon Falco cherrug in Hungary between 1980 and 2002, 663-672. In: Chancelor RD \& Meyburg B-U (eds), Raptors Worldwide. Proceedings of the world conference on bird of prey and 
owl. Budapest. Working group on birds of prey and owls, MME/ Birdlife Hungary, Berlin \& Budapest, 867.

Bagyura J, Szitta T, Haraszthy L, Fidloczky J, Prommer M, Solti B, Fater I, Dudas M, Tihanyi G, Zalai T, Vaczi M, Viszlo L, Klebert A, Kazi R, Puskas L, Toth I \& Torok HA 2006: Annual report of the saker falcon working group Hungary 2006. MME/BirdLife Hungary, 25. [in Hungarian]

Bagyura J, Fidlóczky J, Szitta T, Prommer M, Tihanyi G, Zalai T, Balázs I, Váczi M, Viszló L, Klébert A, Haraszthy L, Tóth I, Török H, A., Demeter I, Serföző J, Pigniczki C \& Kazi R 2009: Annual report of the saker falcon working group - 2009. MME/BirdLife Hungary, 9.

Bennett F, Hinsley SA, Bellamy PE, Swetnam RD \& MacNally R 2004: Do regional gradients in land-use influence richness, composition and turnover of bird assemblages in small woods? Biological Conservation 119: 191-206. DOI: 10.1016/j.biocon.2003.11.003

Benton TG, Vickery JA \& Wilson JD 2003: Farmland biodiversity: is habitat heterogenity the key? Trends in Ecology \& Evolution 18: 182-188. DOI: 10.1016/S0169-5347(03)00011-9

Beran V, Škorpíková V, Valášek M, Horal D \& Horák P 2012: The breeding population of saker falcon (Falco cherrug) in the Czech Republic between 1999-2010. Aquila 119: 21-30.

Blair RB 1996: Land use and avian species diversity along an urban gradient. Ecological Applications 6: 506-519. DOI: $10.2307 / 2269387$

Chavko J 2002: Sokol rároh (Falco cherrug) [The Saker Falcon (Falco cherrug)], 214-216. In: Danko Š, Darolová A \& Krištín A (eds): Rozšírenie vtákov na Slovensku. [Birds distribution in Slovakia.] Veda, Bratislava, 688. [In Slovak with English summary]

Chavko J 2010: Trend and conservation of saker falcon (Falco cherrug) in Western Slovakia between 1976 and 2010. Slovak Raptor Journal 4: 1-22. DOI: 10.2478/v10262-012-0040-4

Chavko J 2013: Zrkadlá - stresový faktor v polobúdkach (Mirrors - stress factor in nest boxes). Dravce a sovy 2(9): 12-13. [In Slovak with English summary]

Chavko J, Deutschová L 2012: Population of saker falcon (Falco cherrug) in Western Slovakia between 1976 and 2010. Aquila 119: 57-64.

Crooks KR, Suarez AV \& Bolger DT 2004: Avian as- semblages along a gradient of urbanization in a higly fragmented landscape. Biology Conservation 115: 451-462. DOI: 10.1016/S0006-3207(03)00162-9

Dixon A, Ragyov D, Ayas Z, Deli M, Demerdzhiev D, Angelov I, Kmetova E \& Nedyalkov N 2009: Population status of breeding saker falcons (Falco cherrug) in Turkey. Avian Biology Research 2: 213-220. DOI: $10.3184 / 175815509 X 12570973331837$

Ellis DH, Ellis MH \& Tsengeg P 1997: Remarkable saker falcon (Falco cherrug) breeding records for Mongolia. Journal of Raptor Research 31: 234-240.

Ferianc O 1977: Vtáky Slovenska 1. Veda, Bratislava, 682.

Frey H \& Senn H 1980: Zur Ernahrung des Wurgfalken (Falco cherrug) und Wander-falken (Falco peregrinus) in den niederosterreichischen Kalkvoralpen. Egretta 23: 31-38

Hansenclover H, Kostrzewa A \& Kostrzewa R 1989: Brutbiologie des Turmfalken (Falco tinnunculus): 16jährige Untersuchungen in Westfalen. Journal of Ornithology 130: 229-237.

Hinsley SA \& Bellamy PE 2000: The influence of hedge structure, management and landscape context on the value of hedgerows to birds: A review. Journal of Environmental Management 60: 33-49. DOI: 10.1006/jema.2000.0360

Horák P 1998: Specializace jednoho páru rároha velkého na jižní Moravě [Specialization of a saker falcon pair in South Moravia]. Buteo 10: 85-88. [In Czech with English summary]

Horal D, Horák P \& Štěpánek P 2006: Zajímavé hnízdění raroha velkého (Falco cherrug) na jižní Moravě v roce 2006 [Interesting breeding of saker falcon (Falco cherrug) in South Moravia in 2006]. Crex 26: 73-76. [In Czech with English summary]

Horal D 2008: Zajímavosti z hnízdění jednoho páru raroha velkého (Falco cherrug) v roce 2007 [Interesting things from breeding of a saker falcon pair (Falco cherrug) in 2007]. Crex 28: 130-134. [In Czech with English summary]

Hudec K (ed.) 1977: Fauna ČSSR. Ptáci 2 [Fauna of Czechoslovak Socialist Republic. Birds 2] Academia Praha, 893.

Kostrzewa R \& Kostrzewa A 1993: Der Turmfalke: Überlebensstrategien eines greifvogels. Sammlung Vogelkundeim AULA-Verlag, 34.

Kovalík P, Topercer J, Karaska D, Danko Š. \& Šrank V 2010: Zoznam vtákov Slovenska k 7.4.2010 [The list of birds of Slovakia to 4th of July, 2010]. Ticho- 
droma 22: 97-108. [In Slovak with English summary]

Löbbová D \& Hapl E 2014: Conservation of European ground squirrel (Mammalia: Rodentia) in Slovakia: Results of current reintroduction programme, Slovak Raptors Journal 8: 105-112, DOI: 10.2478/srj-20140012

Losos B, Gulička J, Lellák J \& Pelikán J 1985: Ekologie živočichů [Ecology of animals]. Státní pedagogické nakladatelství, Praha, 316.

Lupták P 2003: Slovenské mená cicavcov sveta [Slovak names of world mammals]. Zoologická záhrada Bojnice, Bojnice, 219.

Mason CF \&, Macdonald SM 2006: Influence of landscape and land-use on the distribution of breeding birds in farmland in eastern England. Journal of Zoology 251: 339-348.

McDonnell MJ \& Pickett STA 1990: Ecosystem structure and function along urban-rural gradients: An unexploited opportunity for ecology. Ecology 4: 1232-1237. DOI: $10.2307 / 1938259$

Mrlík V, Horák P, Bělka T \& Vrána J 1995: Analýza populace raroha velkého (Falco cherrug) v České republice a strategie jeho ochrany [Analysis of saker falcon population (Falco cherrug) in Czech Republic and strategy of its protection]. Buteo 7: 191-192.

Nedyalkov N, Levin A, Dixon A, Boev Z \& 2014: Diet of saker falcon (Falco cherrug) and eastern imperial eagle (Aquila heliaca) from Central Kazakhstan. Ecologia Balkanica 6: 25-30.
Nemček V, Chavko J \& Deutschová L 2014: Movement and wind turbines threat for the juvenile saker falcons (Falco cherrug) in SW Slovakia. Slovak Raptors Journal 8: 97-103. DOI: 10.2478/srj-2014-0011

Obuch J \& Chavko J 1997: Potrava sokola rároha (Falco cherrug) na juhozápadnom Slovensku [The saker falcon diet (Falco cherrug) in south-western Slovakia]. Buteo 9: 77-84.

Puzović S 2008: Nest occupation and prey grabbing by saker falcon (Falco cherrug) on power lines in the province of Vojvodina (Serbia). Archives of Biological Science, Belgrade 60: 271-277. DOI: 10.2298/ABS0802271P

Pykal J, Bürger P \& Hora J 1997: Ptačí společenstva nelesních stanovišt' hraničního území Nové Údolí Haidmühle [Bird societies of non-forest stands of Nové Údolí border - Haidmühle]. Sylvia 33: 141-147

Rodewald AD \& Yahner RH 2001: Influence of landscape composition on avian community structure and associated mechanims. Ecology 82: 3493-3504.

Ter Braak CJF \& Šmilauer P 2002: CANOCO Reference manual and CanoDraw for Windows. User's guide. Software for canonical community ordination, ver. 4.5. Microcomputer Power, Ithaca, NY, 500.

Trnka A 2002: Jarabica pol'ná (Perdix perdix) [The Grey Partridge (Perdix perdix)], 225-227. In: Danko Š, Darolová A \& Krištín A (eds): Rozšírenie vtákov na Slovensku [Birds distribution in Slovakia]. Veda, Bratislava, 688. [In Slovak with English summary] 